\title{
Finite element analysis of the flexural behavior of square CFST beams at ambient and elevated temperature
}

\author{
M. F. Javed ${ }^{a}$, N. H. Ramli Sulong ${ }^{a^{*}}$, N.B. Khan ${ }^{a}$, S. Kashif ${ }^{a}$ \\ ${ }^{\mathrm{a} D e p a r t m e n t ~ o f ~ C i v i l ~ E n g i n e e r i n g, ~ F a c u l t y ~ o f ~ E n g i n e e r i n g, ~ U n i v e r s i t y ~ o f ~ M a l a y a, ~ M a l a y s i a ~}$ \\ *corresponding author, email address: hafizah_ramli@um.edu.my
}

\begin{abstract}
This paper presents the finite element (FE) analysis and modeling of square concretefilled steel tube (CFST) members subjected to a flexural load at ambient and elevated temperature. The commercial FE tool ANSYS was used in the 3D modeling taking into consideration material and geometric non-linearities. The developed FE model can accurately predict the ultimate moment capacity of the square CFST members subjected to flexural loads and fire resistance time. A parametric study is conducted using the verified FE model to study the effect of the compressive strength of infilled concrete and the yield strength of the steel tube on the flexural behavior of the square CFST members. The ultimate bending capacity of the CFST members increases by up to $27 \%$ when the yield strength of the steel tube increases from $210 \mathrm{MPa}$ to $400 \mathrm{MPa}$ while its fire resistance time decreases. For a $\mathrm{D} / \mathrm{t}$ ratio equal to 30 , the flexural capacity increases by $20 \%$ when the compressive strength of the infilled concrete increases from $60 \mathrm{MPa}$ to $100 \mathrm{MPa}$, while it shows increase in fire resistance time.
\end{abstract}

Keywords: Flexural behavior; square concrete-filled steel tube; finite element analysis; ambient and elevated temperature.

\section{Introduction}

The use of CFST columns and beams in constructing buildings has increased exponentially in the recent decades $[1,2]$. As suggested by structural engineers, CFST members are the most interesting composite members for several modern building projects [3-5]. This type of composite member has more advantages than conventional hollow steel/concrete members, such as faster construction work because of the omission of reinforcing bars and framework, low structure cost, conservation of environment, high ductility and strength capacity [6].

A lot of studies have been conducted on CFST columns at ambient and elevated temperature. However, there are very limited studies on the flexural behavior of CFST at ambient temperature while to date, no study has been conducted on the flexural behavior of CFST beams at elevated temperature. Also, only a few studies on the numerical analysis of the structural performance of CFSTs in bending are available in the literature $[7,8]$.
$\mathrm{Hu}$ et al. [7] proposed a material constitutive model for circular CFST columns subjected to pure bending. They performed a finite element analysis (FEA), validated the theoretical results with the experimental data, and concluded that concrete is an ideal material that resists compressive loading in typical applications when the depth-to-thickness (D/t) ratio is greater than 74 . The infilled concrete has no significant effect on the strength of CFST columns when the $\mathrm{D} / \mathrm{t}$ ratio is less than 20. However, there is no study available in literature to model the high strength infilled concrete filled steel tube subjected to flexural load only.

Based on the research gaps in the area of flexural performance of CFST beam at ambient and elevated temperature, this study aims to investigate the flexural behavior of CFST beams numerically by using the commercial FEA package ANSYS [9]. This investigation employs the FEA modeling technique taking into consideration the interaction of concrete and steel, non- 
linearities of material, geometrical imperfection, and changes in the material properties and strength reduction during exposure to fire. The type of element and the size of mesh also carefully selected as they affect the accuracy and computational time of the model. The FEA model is verified with the experimental results available in the literature. The numerical analysis is then extended to perform a parametric study on the effects of the compressive strength of concrete and the yield strength of steel on the performance of CFST beams under flexural loads.

\section{Details of the FE model at ambient temperture}

\subsection{General}

The commercial FE tool ANSYS was used to study the flexural behavior of CFST beams and two basic materials were considered to model the behavior. Steel was used to model the outer tube while the inner core was defined with concrete material.

\subsection{FE type, meshing and boundary conditions}

A simply supported hollow steel beam filled with concrete under two-point loading was used to investigate the flexural behavior and strength. The steel tube was modeled using a 3D hexahedral reduced integration solid element, and the concrete was modeled using a 3D quadrilateral reduced integration solid element. The interface between the steel tube and the infilled concrete was modeled using the "hard point contact" formulation.

A convergence study was performed to select the appropriate mesh size of the FE model of the square CFST beam. Ultimate flexural capacity calculated from different meshes were compared with experimental results of Gho and Liu [10]. The FE model with 13080 elements was selected based on the time taken by the workstation and without compromising the accuracy of the FE model.

Accurate boundary conditions had to be applied on the nodes lying on the symmetry plane to reflect the accurate flexural behavior. Hinge supports were defined by constraining the nodes in the y-direction and allowing free movement in the $\mathrm{x}$ and $\mathrm{z}$ directions. Both supports were located at $100 \mathrm{~mm}$ from the free ends.

\subsection{Material modeling \\ 2.3.1 Steel}

The model for structural steel suggested by Han et al. [11] was used for the uniaxial stress-strain relation of the steel. Hardening of the structural steel was considered in this model. The deformation of steel includes elastic, elastic-plastic, plastic, hardening, and fracture, as shown in Fig. 1, where $f_{p}, f_{y}$, and $f_{u}$ represents the proportional limit, yield, and ultimate strength of steel at their relevant strains, respectively; $\quad \varepsilon_{e}=0.8 f_{y} / E_{s}, \varepsilon_{y}=$ $1.5 \varepsilon_{e}, \varepsilon_{u y}=10 \varepsilon_{y}$ and $\varepsilon_{u}=100 \varepsilon_{y}$. The modulus of elasticity and the Poisson's ratio for the steel were $2 \times 10^{5} \mathrm{~N} / \mathrm{mm}^{2}$ and 0.3 , respectively.

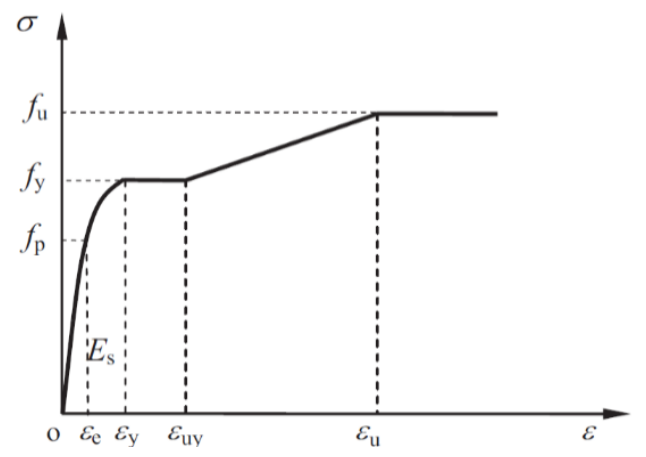

Fig. 1. Schematic diagram of the uniaxial stressstrain relation for steel [1].

\subsubsection{Concrete}

The stress-strain model presented by Han et al., [12] for square CFST columns was used to model the square CFST in this study. The equations are given below.

$$
y=f(x)=\left\{\begin{array}{cl}
2 x-x^{2}, & x \leq 1 \\
\frac{x}{\beta_{0}(x-1)^{\eta}+x}, & x>0
\end{array}\right.
$$

Where $x=\varepsilon / \varepsilon_{0}, \quad y=\sigma / \sigma_{0} ; \sigma_{0}=f^{\prime}{ }_{c}$ $(\mathrm{MPa}) ; \quad \varepsilon_{0}=\varepsilon_{c}+800 \xi^{0.2} \times 10^{-6} ; \quad \varepsilon_{c}=$ $\left(1300+12.5 f^{\prime}{ }_{c}\right) \times 10^{-6}$;

$$
\begin{aligned}
& \eta=1.6+1.5 x, \\
& \beta=\frac{\left(f^{\prime}\right)^{0.1}}{1.2 \sqrt{1+\xi}}, \\
& \text { where } \xi=\frac{A_{s} f_{y}}{A_{c} f_{c k}}
\end{aligned}
$$

In the above equations, $\xi$ is the confinement factor, $f_{y}$ is the yield strength of steel, $f_{c k}$ is the characteristics strength of 
concrete and is equal to $0.67 f^{\prime}{ }_{c} ; f^{\prime}{ }_{c}$ is the compressive strength of concrete in $\mathrm{MPa}, A_{s}$ and $A_{c}$ is the area of steel tube and infilled concrete respectively. The modulus of elasticity was calculated using Equation 2.

$$
E_{c}=4700 \sqrt{f^{\prime}}
$$

The Poisson's ratio of concrete was assumed to be 0.2 .

\subsubsection{Interface}

The interface between the infilled concrete and the steel tube of the CFST was modeled in the tangential and normal directions. The "hard point contact" formulation was used for the normal direction, which permits any pressure value when the surfaces are in contact and zero pressure when the surfaces are separated. For the interaction in the tangential direction, the penalty friction formulation with a Coulomb friction coefficient of 0.3 and maximum shear interfacial stress of $0.41 \mathrm{MPa}$ was taken, as suggested by AISC 360-10 [13]. The slippage at the interface could occur when the applied shear stress exceeds 0.3 times the contact pressure.

\subsection{Model verification}

The accuracy and efficiency of the developed FE model were demonstrated through the comparisons between the FE and experimental results with different parameters, as performed by Soundararajan and Shanmugasundaram [14], Uy [15] and Gho and Liu [10]. The ultimate flexural load and load-deflection curves of the CFST beams were considered in verifying the developed FE model. The details of the general experimental setup and the boundary conditions in the FE model are shown in Figs. 2-3, respectively.

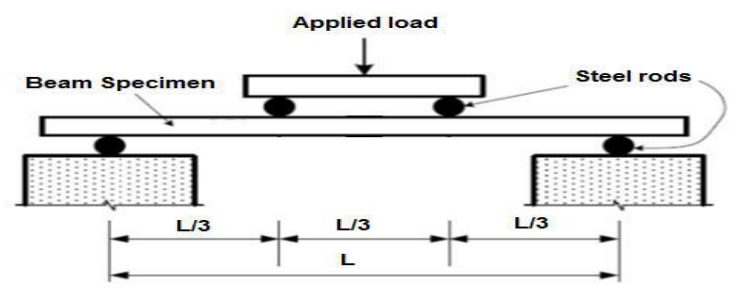

Fig. 2. Details of the general experimental test setup.

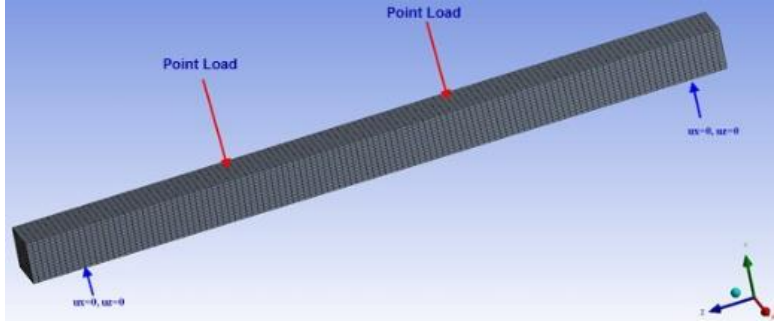

Fig. 3. Boundary conditions and mesh of the modeled beam.

\subsubsection{Ultimate strengths of CFST beams}

Specimens B01 to B04 as reported in Gho and Liu [10] have the compressive strength of the infilled concrete ranged from $56 \mathrm{MPa}$ to 87 $\mathrm{MPa}$, and the modulus of elasticity was 26 $\mathrm{GPa}$. Both square and rectangular beams were tested in the experimental program with different cross-sectional dimensions. However, only square cross sections were considered in the verification. The length of all specimens was $1600 \mathrm{~mm}$. The yield strength of the steel tubes used in the experiments was approximately $438 \mathrm{MPa}$. The beams were tested using two-point loading. The rest of the properties are presented in Table 1.

Specimens HSS 6, 13, and 19 were reported in [15]. The $\mathrm{D} / \mathrm{t}$ ratio of the square specimens ranged from 20 to 30 , and the length of the specimens ranged from $1800 \mathrm{~mm}$ to $3600 \mathrm{~mm}$. The compressive strength of the infilled concrete was $30 \mathrm{MPa}$, and the yield strength of the steel tube was taken as 784 $\mathrm{MPa}$. The ultimate strength and modulus of elasticity of the steel tube were approximately $864 \mathrm{MPa}$ and $200 \mathrm{GPa}$, respectively.

The geometry, material properties, and experimental results of the CFST beams reported in [14] are mentioned in Table 1. The dimensions of the steel tube were kept constant in all the experiments. The specimens were made of normal mix concrete (NMC) and fly ash concrete (FAC). The D/t ratio of the steel tube was maintained at 20.5. All specimens were tested under two-point flexural loads. CFST beams were constructed using concretes with strengths in the range of $21 \mathrm{MPa}$ to $32.6 \mathrm{MPa}$. The yield strength of the steel tubes was $345 \mathrm{MPa}$, and the ultimate stress was $510 \mathrm{MPa}$. 
Table 1. Geometry, material properties, and ultimate moment of specimens used for model verification

\begin{tabular}{lcccccc}
\hline $\begin{array}{c}\text { Specimen } \\
\text { designation }\end{array}$ & $\begin{array}{c}\text { Dimensions, } \\
\text { B x t (mm) }\end{array}$ & $\begin{array}{c}\text { Area of } \\
\text { steel, } \mathrm{A}_{\mathrm{s}} \\
\left(\mathrm{mm}^{2}\right)\end{array}$ & $\begin{array}{c}\text { Area of } \\
\text { concrete, } \mathrm{A}_{\mathrm{c}} \\
\left(\mathrm{mm}^{2}\right)\end{array}$ & $\begin{array}{c}\text { Yield } \\
\text { Strength of } \\
\text { Steel (MPa) }\end{array}$ & $\begin{array}{c}\text { Compressive } \\
\text { strength of } \\
\text { concrete (MPa) }\end{array}$ & $\begin{array}{c}\text { Average } \\
\text { ultimate } \\
\text { moment } \\
(\mathrm{kNm})\end{array}$ \\
\hline NMC 1-3 & $72 \times 3.2$ & 881 & 4303 & 345 & 32.6 & 10.01 \\
FAC 1-3 & $72 \times 3.2$ & 881 & 4303 & 345 & 32.5 & 10.12 \\
B-01 & $150 \times 4.9$ & 2844 & 19656 & 438 & 56.3 & 84.95 \\
B-03 & $150 \times 4.9$ & 2844 & 19656 & 438 & 87.5 & 99.9 \\
HSS-06 & $110 \times 5$ & 2100 & 10000 & 750 & 30 & 66 \\
HSS-13 & $160 \times 5$ & 3100 & 22500 & 750 & 30 & 141 \\
HSS-19 & $210 \times 5$ & 4100 & 40000 & 750 & 32 & 228 \\
\hline
\end{tabular}

Table 2. Comparison of ultimate strengths obtained from experiments and FEA

\begin{tabular}{|c|c|c|c|c|c|c|c|c|}
\hline $\begin{array}{c}\text { Specimen } \\
\text { Designation }\end{array}$ & $\begin{array}{l}\mathrm{P}_{\mathrm{u}, \operatorname{Exp}} \\
(\mathrm{kN})\end{array}$ & $\begin{array}{l}\text { Average, } \\
\mathrm{P}_{\mathrm{u}}(\mathrm{kN})\end{array}$ & $\begin{array}{l}\mathrm{P}_{\mathrm{u}, \mathrm{FE}} \\
(\mathrm{kN})\end{array}$ & $\begin{array}{l}\mathrm{M}_{\mathrm{u}, \operatorname{Exp}} \\
(\mathrm{kNm})\end{array}$ & $\begin{array}{l}\text { Average } \\
\mathrm{M}_{\mathrm{u}, \operatorname{Exp}} \\
(\mathrm{kNm})\end{array}$ & $\begin{array}{l}\text { Ultimate } \\
\text { Moment FE, } \\
\mathrm{M}_{\mathrm{u}, \mathrm{Num}} \\
(\mathrm{kNm})\end{array}$ & $\mathrm{M}_{\mathrm{u}, \mathrm{Num}} / \mathrm{M}_{\mathrm{u}, \exp }$ & Reference \\
\hline NMC-1 & 61 & \multirow{2}{*}{60.67} & \multirow[t]{2}{*}{61} & 10.06 & \multirow{2}{*}{10.01} & \multirow{2}{*}{10.07} & \multirow{2}{*}{1.01} & \multirow{4}{*}[14]{} \\
\hline NMC-2 & 58 & & & 9.57 & & & & \\
\hline FAC-1 & 60 & \multirow[t]{2}{*}{61.33} & \multirow{2}{*}{61} & 9.9 & \multirow[t]{2}{*}{10.12} & \multirow[t]{2}{*}{10.07} & \multirow[t]{2}{*}{1} & \\
\hline FAC-2 & 61 & & & 10.07 & & & & \\
\hline B-01 & 451.32 & 468.695 & 455.18 & 81.8 & 84.95 & 82.5 & 0.98 & \multirow{2}{*}[10]{} \\
\hline B-03 & 542.9 & 551.175 & 557.25 & 98.4 & 99.9 & 101 & 1.02 & \\
\hline HSS-6 & 220 & 220 & 226.67 & 66 & 66 & 68 & 1.04 & \multirow{3}{*}[15]{} \\
\hline HSS-13 & 376 & 376 & 381.33 & 141 & 141 & 143 & 1.02 & \\
\hline HSS-19 & 456 & 456 & 464 & 228 & 228 & 232 & 1.02 & \\
\hline \multicolumn{6}{|c|}{ Mean } & & \multicolumn{2}{|c|}{1.02} \\
\hline \multicolumn{6}{|c|}{ Standard Deviation (SD) } & & \multicolumn{2}{|c|}{0.02} \\
\hline \multicolumn{6}{|c|}{ Co-efficient of Variation (COV) } & & \multicolumn{2}{|c|}{0.02} \\
\hline
\end{tabular}

Table 2 shows the experimental and computational ultimate flexural strengths of CFST beams, where $\mathrm{P}_{\mathrm{u} \text {,exp }}$ denotes the experimental ultimate flexural strength and $\mathrm{P}_{\mathrm{u}, \mathrm{FE}}$ represents the ultimate flexural strength predicted by the FE model. The predicted ultimate flexural strengths of the tested specimen were in good agreement with the experimental results. The mean ultimate flexural strength predicted by the numerical model $\left(\mathrm{M}_{\mathrm{u}, \mathrm{Num}}\right)$ was 1.04 times the experimental value $\left(\mathrm{M}_{\mathrm{u}, \exp }\right)$, with a standard deviation (SD) of 0.02 and a coefficient of variation $(\mathrm{COV})$ of 0.02 .

The load-deflection curves for the FAC [14] and HSS [15] predicted by the FE model and obtained from the experiments are shown in Fig. 4. The load-deflection curve predicted by the numerical model was in good agreement with the experimental results.

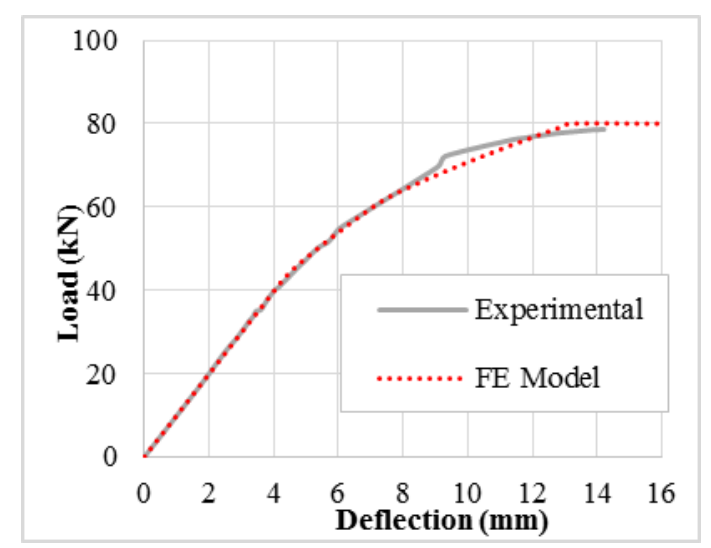

(a) 


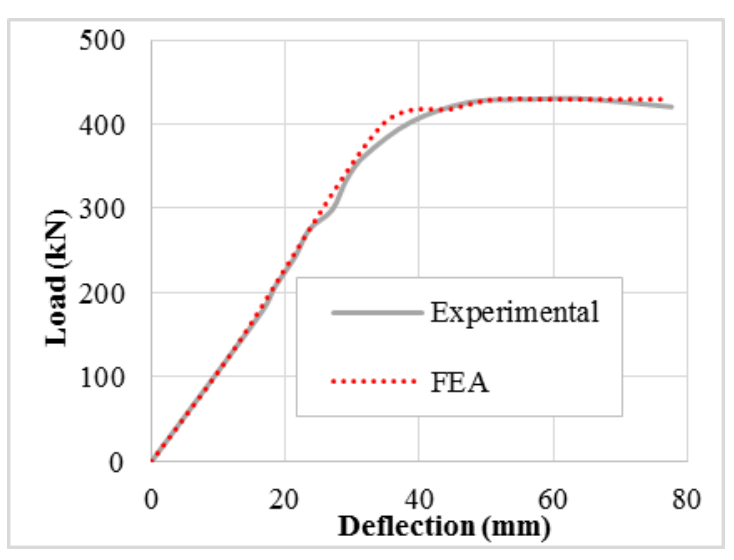

(b)

Fig. 4. Load-deflection curves comparison of samples (a) FAC [14] and (b) HSS-19 [15] with the FE model.

\section{FE Model at elevated temperature}

\subsection{General}

The FE model explained in Section 2 was extended for the modeling of square CFST member at elevated temperature. The element types for square steel tube and infilled concrete are similar to the elements for ambient case. The details of the mesh used for CFST beams is shown in Fig. 5. Mesh convergence study was performed to select the reasonable number of elements and its size. A surface based interaction with a Coulomb friction model hard contact pressure model in the tangential and normal direction, respectively, were used to model the interface between steel and concrete core. The friction factor was taken as 0.6.

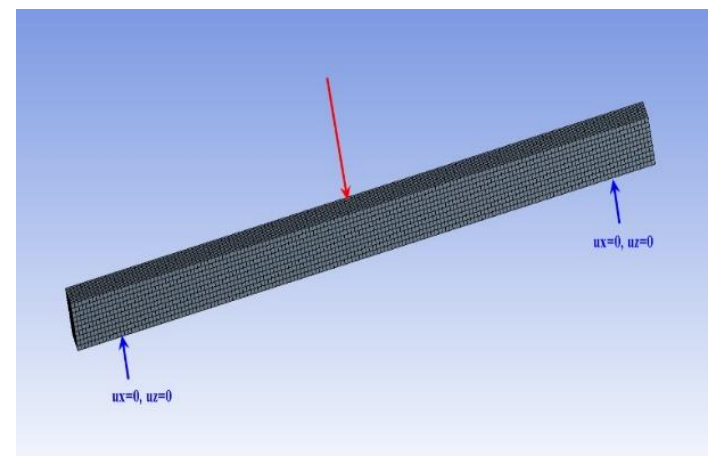

Fig. 5. FE model with load applied and support conditions.

\subsection{Material modeling}

The elevated temperature model was based on thermal analysis in ANSYS software. The values of governing parameters in the model is given in Table 3.
Table 3. Material properties for elevated temperature model

\begin{tabular}{lc}
\hline \multicolumn{1}{c}{ Parameters } & Values \\
\hline $\begin{array}{l}\text { Constant convective coefficient } \\
\text { for exposed surface }\end{array}$ & $25 \mathrm{~W} / \mathrm{m}^{2} \mathrm{~K}$ \\
$\begin{array}{l}\text { Constant convective coefficient } \\
\text { for unexposed surface }\end{array}$ & $9 \mathrm{~W} / \mathrm{m}^{2} \mathrm{~K}$ \\
$\begin{array}{l}\text { Steel emissivity value } \\
\text { Stefan-Boltzmann constant }\end{array}$ & 0.8 \\
$\begin{array}{l}\text { Thermal expansion coefficient } \\
\text { for steel } \\
\text { Thermal expansion coefficient } \\
\text { for concrete }\end{array}$ & $12 \times 10^{-6} /{ }^{\circ} \mathrm{C}$ \\
\hline
\end{tabular}

The degradation of steel material properties at elevated temperature is based on the strength reduction factor as suggested by EC3:1-2 [16]. For concrete, the constitutive model presented by Han et al. [17] was employed as it takes into account the effect of bonding between concrete and steel.

\subsection{Model verification}

The developed FE model was verified with the experimental results conducted by the authors. Only brief experimental results were explained here. Two simply supported square CFST specimens have a span of $3200 \mathrm{~mm}$, with only the central part of length $2800 \mathrm{~mm}$ was exposed to fire. The square section is 150x150 mm with $6 \mathrm{~mm}$ thickness. All the specimens were filled with normal aggregate concrete and subjected to flexural load. The details of beam and application of load and support conditions are shown in Fig. 6. The applied load was kept constant while the temperature was increased according to ISO834 curve. The nominal load ratio, $n$ of all the specimens was 0.30 . The measured yield strength, ultimate strength, elastic modulus and maximum elongation were $394 \mathrm{MPa}, 458$ $\mathrm{MPa}, 201.3 \mathrm{GPa}$ and 29\%, respectively. Concrete material with normal aggregate has a compressive strength of $55 \mathrm{MPa}$.

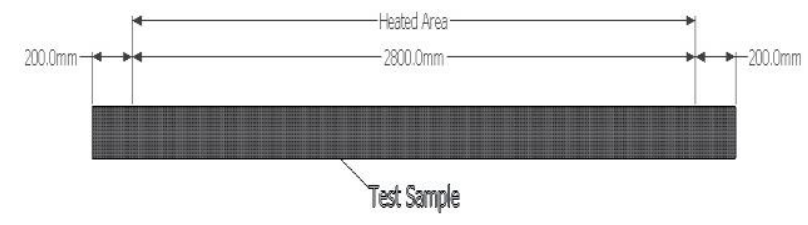

Fig. 6. Test sample showing heated length of specimen. 
The mid-span deflection obtained from FE model and the measured mid-span deflection during test are compared in Fig. 7. It must be noted from that the displacement predicted by FE model at the time of failure is less than the experimentally measured displacement. This may be due to the neglecting the effect of creep in the FE model as the creep is pronounced at elevated temperature [18].

The FR time obtained from test results and FE model are presented in Table 4. The close resemblance of results between FE model and test results shows that the co-efficient of thermal expansion used for concrete, steel and steel-concrete interface are accurate and can be used in future research works.

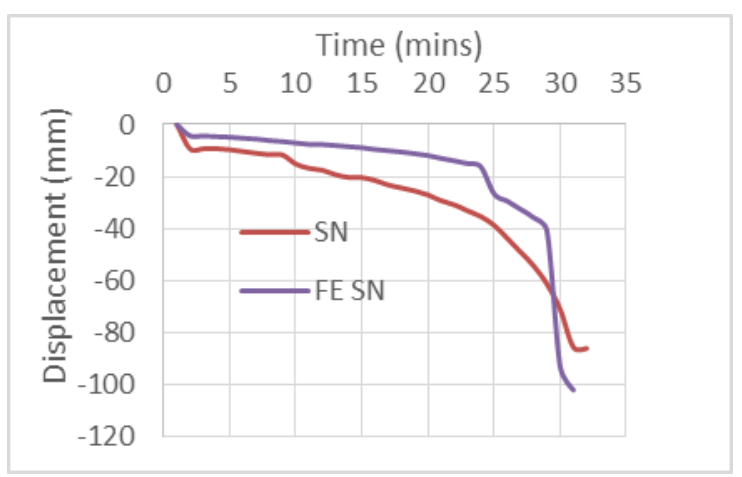

Fig. 7. Comparison of time-displacement curves at elevated temperature.

Table 4. FR time for experimental and Numerical models

\begin{tabular}{lllr}
\hline Specimens & $\begin{array}{l}\text { FR time, } \\
\text { mins } \\
\text { (Exp) }\end{array}$ & $\begin{array}{l}\text { FR time, } \\
\text { mins } \\
\text { (Num) }\end{array}$ & Exp/Num \\
Square 1 & 28 & 27.5 & 1.02 \\
Square 2 & 28.5 & 27.2 & 1.05 \\
\hline
\end{tabular}

\section{Parametric study}

An extensive parametric study was performed to investigate the influences of the concrete compressive strengths and steel yield strengths on the fundamental behavior of the CFST beams under the flexural load only both at ambient and elevated temperature. Only one variable was considered at a time to assess its individual effect. Three different concrete strengths with a range of steel yield strengths were selected.

\subsection{Effect of concrete grade}

The effect of compressive strengths on the ultimate capacity and behavior of CFST beams was studied using the FE model. In the parametric study, the compressive strength of concrete varied from $60 \mathrm{MPa}$ to $100 \mathrm{MPa}$. Both the depth and width of the steel tube were kept constant at $80 \mathrm{~mm}$. The steel tube wall was $2.5 \mathrm{~mm}$ thick, so that its $\mathrm{D} / \mathrm{t}$ ratio was 30. The steel yield and ultimate strengths were $345 \mathrm{MPa}$ and $510 \mathrm{MPa}$, respectively, and the modulus of elasticity was $200 \mathrm{GPa}$. The flexural load-deflection curves for the CFST beams with different concrete strengths are shown in Fig. 8. The ultimate flexural strengths of square CFST beams increase 20\% with the increase in the compressive strength of the concrete from 60 to $100 \mathrm{MPa}$.

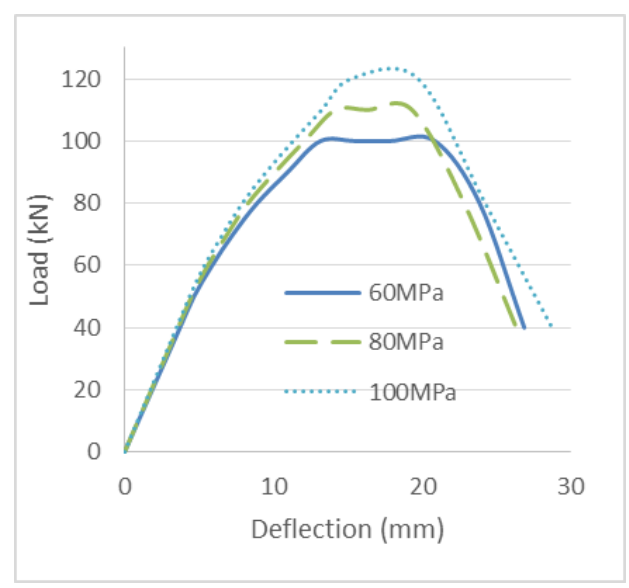

Fig. 8. Load-deflection curve of square CFST for different compressive strengths of concrete infill.

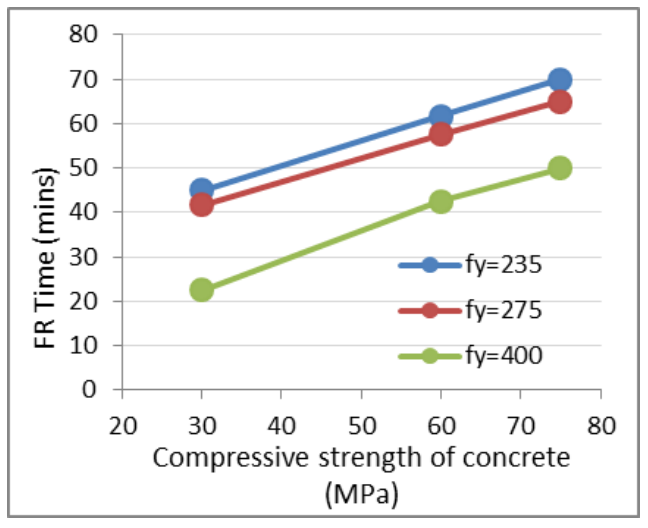

Fig. 9. FR time of beams for different compressive strengths of concrete.

Fig. 9 shows the effect of compressive strength of concrete on fire resistance (FR) time for various yield strengths of steel. By increasing the compressive strength of infilled concrete, the FR time increases regardless of 
the yield strength of steel tube. Similar conclusions were made by researchers for concrete filled stainless steel members subjected to axial load at elevated temperature [19].

\subsection{Influence of steel yield strengths}

The square CFSR beams with different steel yield strengths and a cross section of 80 $\mathrm{mm} \times 80 \mathrm{~mm}$ with the same $\mathrm{D} / \mathrm{t}$ ratio of approximately 30 were analyzed using the FE model. The steel tubes with 30 and $60 \mathrm{MPa}$ concrete that had a modulus of elasticity of $32600 \mathrm{MPa}$ were considered.

Fig. 10 illustrates the influences of the steel yield strengths on the flexural load-deflection curves of the square CFST beams. The yield strength of the steel did not affect the initial stiffness of the beams. However, the ultimate flexural strength of the square CFST beams increased significantly with the increase in the steel yield strength. The ultimate flexural load of the square CFST beam increased by $27 \%$ with the increasing in the steel yield strength from $210 \mathrm{MPa}$ to $400 \mathrm{MPa}$.

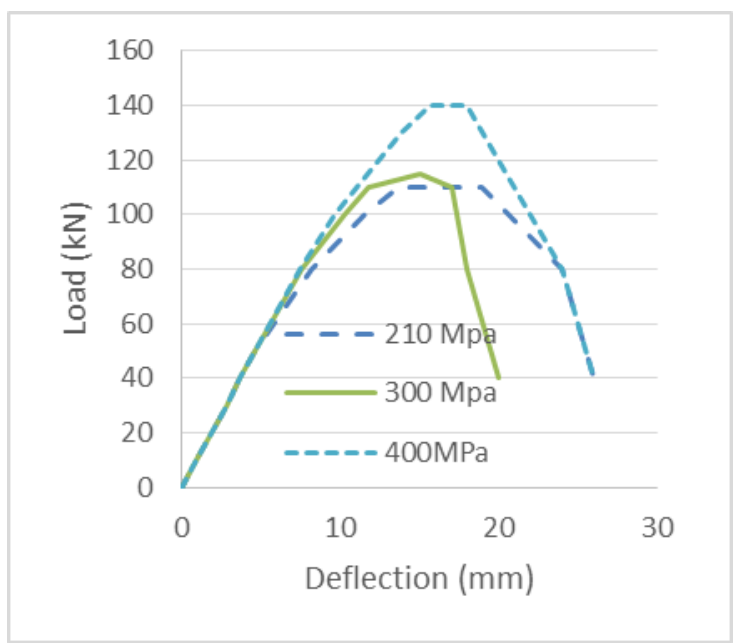

Fig. 10. Load-deflection curve of square CFST for different types of steel.

Fig. 11 shows the influence of yield strength of steel on the fire resistance time of CFST members subjected to flexural load only. For both sets of concrete strength, increase in yield strength of steel causes decrease in the fire resistance time of CFST beam. It should be kept in mind that the load taken by high strength steel is more as load ratio was kept constant.

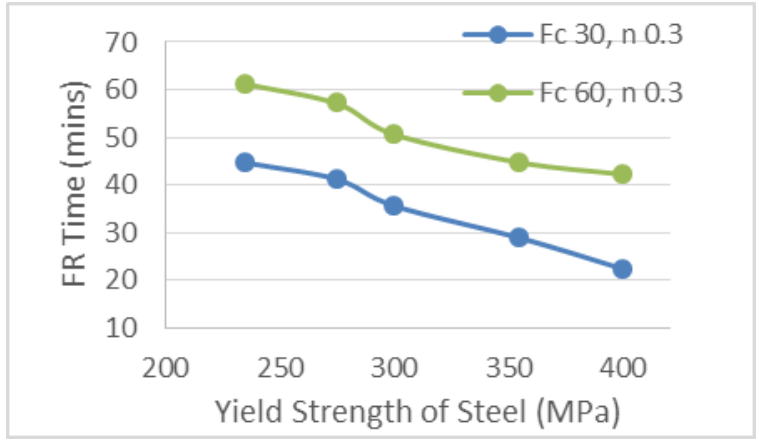

Fig. 11. FR time values for different yield strengths of steel.

\section{Conclusions}

The finite element model is proposed to investigate the flexural behavior of square concrete filled steel tube (CFST) members at ambient and elevated temperatures. The predicted model for the load-deflection curves and the ultimate moment capacity are found in good agreement with the experimental results. The predicted model at elevated temperature shows a reasonable aggreement of timedisplacement curves with the experimental results. The finite element model is used for parametric investigation of the effect of different steel and concrete materials with similar D/t ratio of 30 of a square CFST at ambient and elevated temperatures. The ultimate moment capacity of the CFST was increased by about $27 \%$, when the yield strength of steel is changed from 210 to 400 $\mathrm{MPa}$. Varying the compressive strength from 60 to $100 \mathrm{MPa}$ has increased $20 \%$ of the ultimate moment capacity. Increasing compressive strength of infilled concrete results in increase in FR time of CFST beams while increased yield strength of steel have negative effect on FR time.

\section{Acknowledgements}

This research was supported by University Malaya Postgraduate Research Fund (PPP Project No. PG155-2015B).

\section{References}

[1] Han LH, Li W, Bjorhovde R. Developments and advanced applications of concrete-filled steel tubular (CFST) structures: Members. Journal of Constructional Steel Research, 2014;100:211-228.

[2] Javed MF et al. FE modelling of the flexural behaviour of square and rectangular steel tubes 
filled with normal and high strength concrete. Thin-Walled Structures 2017;119:470-481.

[3] Liew JR, Xiong D. Ultra-high strength concrete filled composite columns for multistorey building construction. Advances in Structural Engineering 2012;15(9):1487-1503.

[4] Liew JR, Xiong M, Xiong D. Design of high strength concrete filled tubular columns for tall buildings. J High-rise Build 2014;3:1-7.

[5] Javed MF et al. Recent research on coldformed steel beams and columns subjected to elevated temperature: A review. Construction and Building Materials 2017;144:686-701.

[6] Qu X, Chen Z, Sun G. Axial behaviour of rectangular concrete-filled cold-formed steel tubular columns with different loading methods. Steel and Composite Structures 2015;18(1):71-90.

[7] $\mathrm{Hu} \mathrm{H}, \mathrm{Su} \mathrm{F}$, Elchalakani M. Finite element analysis of CFT columns subjected to pure bending moment. Steel and Composite Structures 2010;10(5):415-428.

[8] Kvedaras AK et al. Analysis of behaviour for hollow/solid concrete-filled CHS steel beams. Steel and Composite Structures 2015;19(2):293-308.

[9] Guide AC-SM. Ansys Inc. Canonsburg, PA; 2010.

[10] Gho WM, Liu D. Flexural behaviour of highstrength rectangular concrete-filled steel hollow sections. Journal of Constructional Steel Research 2004;60(11):1681-1696.

[11]Han LH, Zhao XL, Tao Z. Tests and mechanics model for concrete-filled SHS stub columns, columns and beam-columns. Steel and Composite Structures 2001;1(1):51-74.

[12] Han LH, Yao GH, Tao Z. Performance of concrete-filled thin-walled steel tubes under pure torsion. Thin-Walled Structures 2007;45(1):24-36.

[13] Cao WG et al. Specification for structural steel buildings. Zhongguo Gonglu Xuebao(China Journal of Highway and Transport) 2012;25(2):90-99.

[14] Soundararajan A, Shanmugasundaram K. Flexural behaviour of concrete-filled steel hollow sections beams. Journal of Civil Engineering and Management 2008;14(2):107114.

[15] Uy B. Strength of short concrete filled high strength steel box columns. Journal of Constructional Steel Research 2001;57(2):113134.

[16]EN1993 Design of steel structures-Part 1-2: Structural fire design. Brussels (Belgium): European Committee for Standardization, CEN; 2005.
[17] Han LH et al. Experimental study and calculation of fire resistance of concrete-filled hollow steel columns. Journal of Structural Engineering 2003;129(3):346-356.

[18] Abid $M$ et al. High temperature and residual properties of reactive powder concrete-A review. Construction and Building Materials 2017;147:339-351.

[19] Han LH et al. Fire performance of concrete filled stainless steel tubular columns. Engineering Structures 2013;56:165-181. 